\title{
KARAKTERISTIK PASIEN MENOPAUSE YANG BEROBAT DI POLIKLINIK PENYAKIT DALAM RSU ANUTAPURA PALU TAHUN 2017
}

\author{
Ali Fauzi Bachmid ${ }^{1}$, Salmah Suciaty ${ }^{1 *}$, John A. Caput ${ }^{1}$ \\ ${ }^{1}$ Program Studi Pendidikan Dokter, Fakultas Kedokteran Universitas Alkhairat, Jl. Diponegoro No. 39 \\ Palu 94221, Sulawesi Tengah, Indonesia
}

*Corresponding author: Telp: +628124245438 email: salmah.suciaty@yahoo.co.id

\begin{abstract}
ABSTRAK
Menopause merupakan proses fisiologis yang akan dialami oleh semua wanita yang berusia $\geq 45$ tahun dan mempunyai gejala yang berbeda-beda dan mempunyai dampak terhadap kesehatan seperti penurunan kualitas hidup pada pasien menopause serta menyebabkan terjadinya gangguan psikososial. Penelitian ini bertujuan untuk mengetahui karakteristik pasien menopause yang berobat dii Polikinik Penyakit Dalam RSU Anutapura Palu Tahun 2017. Penelitian ini adalah jenis penelitian deskriptif kategorik dengan pendekatan penelitian adalah cross sectional study. Pengumpulan data dilakukan dengan menggunakan tekhnik random sampling, yang kemudian dilakukan wawancara dan pemeriksaan fisik kepada pasien menopause. Karakteristik pada 62 pasien menopause di Poliklinik Penyakit Dalam RSU Anutapura Palu ditemukan pasien menopause yang mengalami inkontinensia $(98,4 \%)$, kelainan kulit berupa hiperpigmentasi $(51,6 \%)$, dan status gizi berat badan obes/overweight $(54,9 \%)$, normal $(37,1 \%)$, berat badan kurang $(8,1 \%)$. Kesimpulan bahwa karakteristik pasien menopause di poliklinik penyakit dalam RSU Anutapura ditemukan banyak pasien mengalami inkontinensia urin, kelainan kulit dominan ditemukan adanya hiperpigmentasi, dan status gizi berlebih sangat dominan.
\end{abstract}

Kata Kunci : Menopause, Inkontinensia, Hiperpigmentasi, Status gizi

\section{ABSTRACT}

Menopause is a physiological process that will be experienced by all women aged $\geq 45$ years and have different symptoms and have an impact on health such as decreased quality of life in menopausal patients and cause psychosocial disorders. This study aims to determine the characteristics of menopausal patients who seek treatment at Internal Medicine Polycyclic Anutapura Hospital in 2017. This research is a categorical descriptive study with a crosssectional study approach. Data collection was carried out using random sampling techniques, which then conducted interviews and physical examinations to menopausal patients. Characteristics of 62 postmenopausal patients in the Internal Medicine Polyclinic in Anutapura General Hospital Palu found menopause patients experiencing incontinence (98.4\%), skin disorders in the form of hyperpigmentation (51.6\%), and nutritional status of obesity / overweight weight (54.9\%), normal (37.1\%), underweight (8.1\%). The conclusion that the characteristics of menopausal patients in the polyclinic in Anutapura General Hospital found that many patients had urinary incontinence, dominant skin abnormalities were found to have hyperpigmentation, and excess nutritional status was very dominant.

Keywords: Menopause, Incontinence, Hyperpigmentation, Nutritional status

\section{PENDAHULUAN}

Usia lanjut mengandung pengertian adanya perubahan progresif pada organism yang telah mencapai kematangan, perubahan ini bersifat umum dan irreversible (tidak dapat kembali). Ada masalah pokok yang dihadapi wanita lanjut usia yaitu menopause. Menopause adalah keadaan seorang wanita yang telah mengalami periode menstruasi akhir dan sudah tidak (dalam masa) subur yang dikonfirmasi dalam waktu 12 bulan. Menopause merupakan proses biologis dan 
tidak sakit, tapi menopause dapat menyebabkan gejala fisik dan emosional seperti mengganggu tidur, inkontinensia urine, kelainan kulit dan kesehatan emosional yang dapat diobati. ${ }^{1}$

Menopause adalah berhentinya siklus haid, biasanya memiliki tiga transisi perimenopause yang dimulai sejak haid tidak teratur dan adanya keluhan-keluhan berkisar diantara umur 45 tahun sampai 55 tahun, menopause berkisar 49-51 tahun, dan postmenopause 52-55 tahun. Perubahan biasanya dimulai dari beberapa tahun sebelum periode menstruasi terakhir dimana terjadi perubahan hormon estrogen dan progesteron. Rata-rata usia wanita yang masuk periode menopause adalah 51. Tapi, beberapa wanita memasuki periode menopause diusia 40 tahun. ${ }^{2,3}$

Penyebab menopause adalah "matinya" (burning out) ovarium.Sepanjang kehidupan seksual seorang wanita, kira-kira 400 folikel primordial tumbuh menjadi folikel matang dan berovulasi, dan beratus-ratus dari ribuan ovum berdegenerasi. Pada usia sekitar 45 tahun, hanya tinggal beberapa folikel-folikel primordial yang akan dirangsang oleh $\mathrm{FSH}$ dan $\mathrm{LH}$, dan produksi estrogen dari ovarium berkurang sewaktu jumlah folikel primordial mencapai nol. Ketika produksi estrogen turun di bawah nilai kritis, estrogen tidak lagi menghambat produksi gonadotropin $\mathrm{FSH}$ dan LH. Sebaliknya, gonadotropin FSH dan LH (terutama FSH) diproduksi sesudah menopause dalam jumlah besar dan kontinu, tetapi ketika folikel primordial yang tersisa menjadi atretik, produksi estrogen oleh ovarium turun secara nyata menjadi nol. ${ }^{4}$

Menopause merupakan proses

fisiologis yang akan dialami oleh semua wanita yang berusia $\geq 45$ tahun dan mempunyai gejala yang berbeda-beda dan mempunyai dampak terhadap kesehatan seperti penurunan kualitas hidup pada pasien menopause serta menyebabkan terjadinya gangguan psikososial. Tujuan penelitian ini adalah untuk mengetahui karakteristik pasien menopause yang berobat di Polikinik Penyakit Dalam RSU Anutapura Palu Tahun 2017.

\section{METODOLOGI}

Penelitian ini menggunakan jenis penelitian deskriptif kategorik dengan pendekatan penelitian adalah cross sectional study . Teknik pengambilan pada penelitian ini menggunakan tehnik Systematic Random Sampling. Besar sampel ditentukan dengan menggunakan rumus Slovin dan diperoleh sampel 62 orang. Semua subjek yang ada dan memenuhi kriteria pemilihan dimasukkan dalam penelitian. Kriteria inklusi yaitu 1) Wanita yang berusia $\geq 45$ tahun 2 ) Sudah tidak menstruasi selama lebih dari 1 tahun 3) Bersedia mengikuti penelitian tanpa paksaan. Wanita $\geq 45$ tahun yang masih mengalami menstruasi dan mengalami cacat fisik (tidak dapat berdiri) dan tidak dapat berkomunikasi dengan baik pada saat dilakukan pengambilan data adalah kriteria eksklusi. Data pada penelitian ini diolah menggunakan perangkat lunak komputer program SPSS 21. Masalah deskripif kategorik dianalisis secara deskriptif untuk variabel kategorik. Hasilnya adalah berupa frekuensi dan presentase (proporsi) yang dapat disajikan dalam bentuk tabel maupun grafik.

\section{HASIL DAN PEMBAHASAN}

\section{HASIL}

\section{Inkontinensia Urin}

Karakteristik pasien menopause yang mengalami inkontinensia urin dapat dilihat pada Tabel 1.

Tabel 1. Distribusi pasien menopause yang mengalami Inkontinensia Urine

\begin{tabular}{ccc}
\hline Inkontinensia Urine & $\mathrm{N}$ & $\%$ \\
\hline Ya & 61 & 98,4 \\
\hline Tidak & 1 & 1,6 \\
\hline Total & 62 & 100,0 \\
\hline
\end{tabular}

Dari tabel 1 di atas, dapat diketahui bahwa sebagian besar $(98,4 \%)$ pasien menopause yang berobat di poliklinik penyakit dalam RSU Anutapura telah mengalami inkontinensia urin. 


\section{Kelainan Kulit}

Karakteristik pasien menopause yang mengalami kelainan kulit dapat dilihat pada Tabel 2.

Tabel 2. Distribusi pasien menopause yang mengalami kelainan kulit

\begin{tabular}{ccc}
\hline Kelainan Kulit & $\mathrm{N}$ & $\%$ \\
\hline Kulit Keriput & 8 & 12,9 \\
\hline Kulit Kendur & 22 & 35,5 \\
\hline Hiperpigmentasi & 32 & 51,6 \\
\hline Elastosis & 0 & 0,0 \\
\hline Total & 62 & 100,0 \\
\hline
\end{tabular}

Dari tabel 2 di atas, dapat diketahui bahwa kelainan kulit yang ditemukan pada penderita menopause yang berobat di poliklinik penyakit dalam RSU Autapura Palu paling banyak $(51,6 \%)$ berupa hiperpigmentasi, diikuti oleh kulit kendur $(35,5 \%)$, dan kulit keriput $(12,9 \%)$. Belum ditemukan penderita yang mengalami elastosis.

\section{Status Gizi}

Karakteristik pasien menopause yang mengalami kelainan kulit dapat dilihat pada Tabel 3.

Tabel 3. Distribusi pasien menopause berdasarkan status gizi

\begin{tabular}{ccc}
\hline Status Gizi & N & $\%$ \\
\hline BB Kurang & 5 & 8,1 \\
BB Normal & 23 & 37,1 \\
Overweight/obes & 34 & 54.9 \\
\hline Total & 62 & 100,0 \\
\hline
\end{tabular}

Dari tabel 3 di atas, dapat diketahui bahwa status gizi yang ditemukan pada penderita menopause yang berobat di poliklinik penyakit dalam RSU Anutapura Palu paling banyak (54.9\%) berupa berat badan berlebih diikuti oleh berat badan normal $(37,1 \%)$, dan berat badan kurang $(8,1 \%)$.

\section{PEMBAHASAN}

1. Distribusi pasien menopause yang mengalami Inkontinensia Urine

Dapat diketahui bahwa sebagian besar $(98,4 \%)$ pasien menopause yang berobat di poliklinik penyakit dalam RSU Anutapura telah mengalami inkontinensia urin.

Menurut studi epidemiologi dilaporkan bahwa Inkontinensia urin dua sampai lima kali lebih sering pada wanita dibandingkan pria, hal ini berhubungan dengan menurunnya hormone estrogen. Akibat bila terjadi penurunan estrogen terutama pada traktus urinarius perempuan menopause adalah perubahan struktur dan fungsi. Estrogen dapat mempertahankan kontinensia dengan meningkatkan resistensi uretra, meningkatkan ambang sensoris kandung kemih, dan meningkatkan sensitivitas $\alpha$ adreno reseptor pada otot polos uretra. ${ }^{5}$

2. Distribusi pasien menopause yang mengalami kelainan kulit

Dapat diketahui bahwa kelainan kulit yang ditemukan pada penderita menopause yang berobat di poliklinik penyakit dalam RSU Autapura Palu paling banyak $(51,6 \%)$ berupa hiperpigmentasi.

Hal ini disebabkan oleh karena terjadi penimbunan pigmen melanin yang tidak teratur di dalam sel basal. Sehingga menyebabkan perubahan pada distribusi pigmen melanin serta berkurangnya proliferasi dan fungsi melanosit dan saat menopause sintesis melanin meningkat (akibat kurangnya regulasi oleh estrogen). Terjadinya bintik dan bercak penuaan pigmen melanin diawali dari tirosin yang merupakan salah satu asam amino esensial dalam tubuh kita mengalami oksidasi, menjadi DOPA dan kemudian berubah menjadi quinone, selanjutnya menjadi indol, dan akhirnya menjadi tumpukan pigmen melanin berupa noda dan bercak penuaan. Semua reaksi ini merupakan reaksi oksidasi. Radikal bebas merupakan agen oksidasi yang sangat kuat sehingga mendorong terjadinya reaksi oksidasi di mana tirosin dengan mudah dan cepat bereaksi untuk membentuk penumpukan indol. Itulah sebabnya mengapa noda atau bercak penuaan seringkali muncul di 
wajah atau bagian tubuh lain yang paling terpajan sinar matahari. ${ }^{6}$

\section{Distribusi pasien menopause berdasarkan status gizi}

Dapat diketahui bahwa status gizi yang ditemukan pada penderita menopause yang berobat di poliklinik penyakit dalam RSU Anutapura Palu paling banyak (54.9\%) berupa berat badan berlebih.

Pada menopause berat badan tidak berhubungan dengan transisi menopause namun perubahan hormon saat menopause bekaitan dengan peningkatan lemak tubuh total dan lemak abdomen. Kelebihan berat badan pada usia paruh baya selain berhubungan dengan peningkatan risiko penyakit kardiovaskuler dan metabolik juga mempengaruhi kualitas hidup serta fungsi seksual. Studi yang dilakukan menunjukkan bahwa kecenderungan akumulasi lemak abdomen sentral dapat diperbaiki dengan terapi estrogen. ${ }^{5}$

Perubahan hormon selama masa perimenopause secara substansial berkontribusi terhadap peningkatan lemak abdomen yang menyebabkan morbiditas fisik dan psikologis.

\section{KESIMPULAN}

Kesimpulan pada penelitian ini yaitu

1. Karakteristik pasien menopause yang mengalami Inkontinensia Urine yaitu sebanyak $(98,4 \%)$

2. Karakteristik pasien menopause yang mengalami kelainan kulit dominan ditemukan dengan hiperpigmentasi sebanyak $(51,6 \%)$
3. Karakteristik status gizi pasien menopause paling banyak yaitu berat badan berlebih $(54.9 \%)$

\section{DAFTAR PUSTAKA}

1. Pfizer. Menopause. http://www.pfizer.ca/sites/g/files/g100170 36/f/201410/Menopause.pdf. Accessed January 19, 2017.

2. National Institute on Aging. Menopause. https://www.nia.nih.gov/sites/default/files/ menopause_2.pdf. Accessed January 19, 2017.

3. Ghani N. Seluk beluk menopause. Media Penelit dan Pengembang Kesehatan. http://ejournal.litbang.depkes.go.id/index. php/MPK/article/download/773/1715. Published 2009. Accessed January 19, 2017.

4. Wulandari L. Terapi sulih hormon alami untuk menopause.

url:http://ejournal.stikesmukla.ac.id/index. php/involusi/article/download/199/197. Accessed January 24, 2017.

5. Suparman E, Rompas J. Inkontinensia urin pada perempuan menopause. Maj Obstet Ginekol Indonesia. http://indonesia.digitaljournals.org/index.p hp/IJOG/article/download/969/963. Published 2008.

6. Praseytowati P. Proses Penuaan Kulit Lansia. USU-e Repository.

7. Oktariyani. Gambaran status gizi pada lanjut usia di Panti Sosial Tresna Werdha (PSTW) Budi Mulya 01 dan 03 Jakarta Timur. http://www.lib.ui.ac.id/file?file=digital/20 301303-S42017-Oktariyani.pdf. Published 2012. 